\title{
DEVELOPMENT OF A CHEST FREEZER - OPTIMUM DESIGN OF AN EVAPORATOR COIL
}

\author{
K. Kalyani Radha ${ }^{1}$, S. Naga Sarada ${ }^{2}$ and K. Rajagopal ${ }^{2}$ \\ ${ }^{1}$ Faculty of Mechanical Engineering, JNTUA College of Engineering, JNTUA \\ Anantapur - 515002, Andhra Pradesh, India; Phone: +91 9440517729. \\ E-mail: kalyaniradha@gmail.com \\ ${ }^{2}$ Faculty of Mechanical Engineering, JNTUH College of Engineering, \\ Kukatpally, Hyderabad-500085, Andhra Pradesh, India.
}

\begin{abstract}
In a country such as India, food grains, fruit, vegetables, meat, poultry and fish, are very susceptible to microbial contamination and spoilage and require stringent preservation methods. One such method is by the use of a chest freezer for the storage of frozen food. This investigation considers different loads and design parameters for the development of a chest freezer using R134a as the working fluid. Experimental designs of an evaporator coil, condenser coil and capillary tube are investigated through the development of storage periods in terms of steady state and cyclic performance, by optimising the quantity of refrigerant charge, with strict adherence to the standards and requirement for maintaining an internal temperature of $-23{ }^{\circ} \mathrm{C}$ at $43{ }^{\circ} \mathrm{C}$ ambient. Cyclic load performance tests optimise the performance of individual components selected for the design of a chest freezer. The system selection has a highly balanced performance with $\mathrm{R} 134 \mathrm{a}$ and showed $118 \mathrm{~kJ} / \mathrm{kg}$ cooling capacity with 8.42 coefficient of performance (COP). By the replacement of $\mathrm{R} 134 \mathrm{a}$, temperatures of $-23{ }^{\circ} \mathrm{C}$ are maintained inside the freezer cabinet with low power consumption and an increase in the net refrigerating effect, which in turn increases the COP. The system design has optimum efficiency with moderate costs by optimising the length and diameter of the evaporator coil, i.e., $34.15 \mathrm{~m}$ and $7.94 \mathrm{~mm}$, respectively.
\end{abstract}

Keywords: Optimisation, evaporator coil, performance, chest freezer, alternate refrigerants, overall heat transfer coefficient.

\section{INTRODUCTION}

CFC12 is the most commonly used refrigerant in small hermetically sealed systems. This is because of its high stability, excellent thermodynamic properties, low index of compression, which makes it suitable for use at extreme pressure ratios and good motor winding cooling characteristics (Lee and Su, 2002; Akash and Said, 2003). HFC134a (tetraflouroethane) is considered to be the most preferred substitute for R12. HFC134a has a $6 \%$ higher capacity at $50{ }^{\circ} \mathrm{F}$ evaporating temperature and $6 \%$ higher at $0{ }^{\circ} \mathrm{F}$ evaporating temperature. Thus, for the same amount of subcooling R134a produces a greater refrigerating effect. The use of oil in an R134a system requires a very stringent quality control. It is not soluble in mineral oil and thus, for R134a POE (ester based) oils are used. This refrigerant contains no chlorine atoms and therefore has negligible ozone depletion potential (Avinash et al., 2005). Most commercial freezers, such as: chest freezers, bottle coolers, visi coolers, display cabinets, water coolers and walk in 
coolers use R134a and R12 as the refrigerant. Estimated annual production of commercial refrigerated cabins (chest freezers, display cabinets, bottle coolers and visi coolers), water coolers and walk in coolers in India is about 40,000, 27,000 and 500 units, respectively. Small and medium enterprises (Ministry of environment and forest, 2005) manufacture about $80 \%$ of these units. Theoretical and experimental studies carried out with an HFC mixture composed of R152a and R125 at different weight percentages (80:20, 85:15 and 90:10) as an alternative to R12 in a domestic refrigerator, reported that the discharge temperature of the mixture was slightly higher than that of R12 (He et al, 2005).

Xuan and Chen (2005) experimented with a ternary mixture R161/R125/ R143a (10:45:45 percentage by weight) and reported that the physical properties of the R161 mixture are similar to those of R502 with environmental properties less than those of R502 and R404A. The coefficient of performance (COP) of the R161 mixture is equal to that of R404A at low evaporator temperatures and its discharge temperature is slightly higher than R404A. The COP of the ternary mixture was greater than R404A at higher evaporator temperatures, while its discharge temperature was lower. Baolian and Zhang (2006) reported that a binary mixture composed of R744 and R290 at 71:29 mole fractions, used as an alternative to R13 in a cascade refrigeration system, has a greater COP and capacity. The performance of a $2801 \mathrm{R} 134 \mathrm{a}$-based domestic refrigerator with liquefied petroleum gas (LPG) composed of R290, R600a and R600 (60:20:20 by mass fraction) as an alternative (Fatouh and El Kafafy, 2006). Experimental investigation with R407C with $10 \%$ and $20 \% \mathrm{HC}$ blend composed of $45 \%$ of R290 and $55 \%$ of R600a (by weight) as an alternative in window air conditioners without changing the mineral oil (Jabaraj et al., 2006). It has been reported that a 19\% increase in the length of the condenser tube is required to suit these mixtures compared with R22. Experimental results reported that R407C with a $20 \% \mathrm{HC}$ blend was found to be a promising alternative to R22 in window air conditioners, without changing the mineral oil. Calm (2006) has investigated 28 different pure refrigerants for chiller applications and reported that R123 currently remains the best option for a reduction in the substantial global warming contributions from chiller and air conditioning applications. R123 has low ODP and very low GWP, very short atmospheric lifetime and the highest energy efficiency of all the current options. Experiments were conducted with two pure $\mathrm{HC}$ refrigerants (R1270 and R290) and three binary mixtures of R1270, R290 and $\mathrm{R} 152 \mathrm{a}$ as alternatives to R502 in low temperature refrigeration applications, having 9.6$18.7 \%$ higher capacity with 17.1-27.3\% higher COP. The compressor discharge temperatures were similar, whilst those of all the other refrigerants were $23.7-27.9^{\circ} \mathrm{C}$ lower than that of R502. The charge requirement was reduced by $60 \%$. The above alternatives offer better performance than R502 and due to their excellent environmental properties, can be used as long-term substitutes for R502 (Park and Jung, 2007).

R12 is the refrigerant used in refrigerators manufactured before 2000. To fulfil the objectives of the Montreal protocol, R12 has to be replaced by either hydrocarbon mixtures or R134a/hydrocarbon mixtures without modification to the existing system (Mohanraj et al., 2009). A review work done by Poggi et al. (2008) examined the relationship between the system architecture, the cooling capacity and the refrigerant charge of the system. It established that the ratio of the cooling capacity versus the refrigerant charge depends on the size of the components; moreover, the amount of refrigerant charge is influenced not only by the volumes of the heat exchangers but also 
by the volumes of the accessories (piping, accumulators, dryers, receivers, filters). For small refrigeration systems, the accessories could greatly influence the system volume and at the same time, the system architecture and the refrigerant charge can influence the performance of the system. In the literature, it is possible to find several experimental and modelling/simulation works regarding the relationship between the refrigerant charge and the performance of the system. These works mainly relate to the heat pump and air conditioning systems but little work is available for chest freezers. The present work investigates freezers working under low temperatures for the storage of frozen food, using a reduced refrigerant charge quantity in the evaporator coil, in order to achieve better system performance.

Chest-type freezers: A chest freezer is nothing but a storage unit for frozen food, such as: meat, poultry, fish, prawns, some vegetables and some fruits. The chest-type freezer provides the most economical type of food freezing mechanism, as shown in Figure 1.

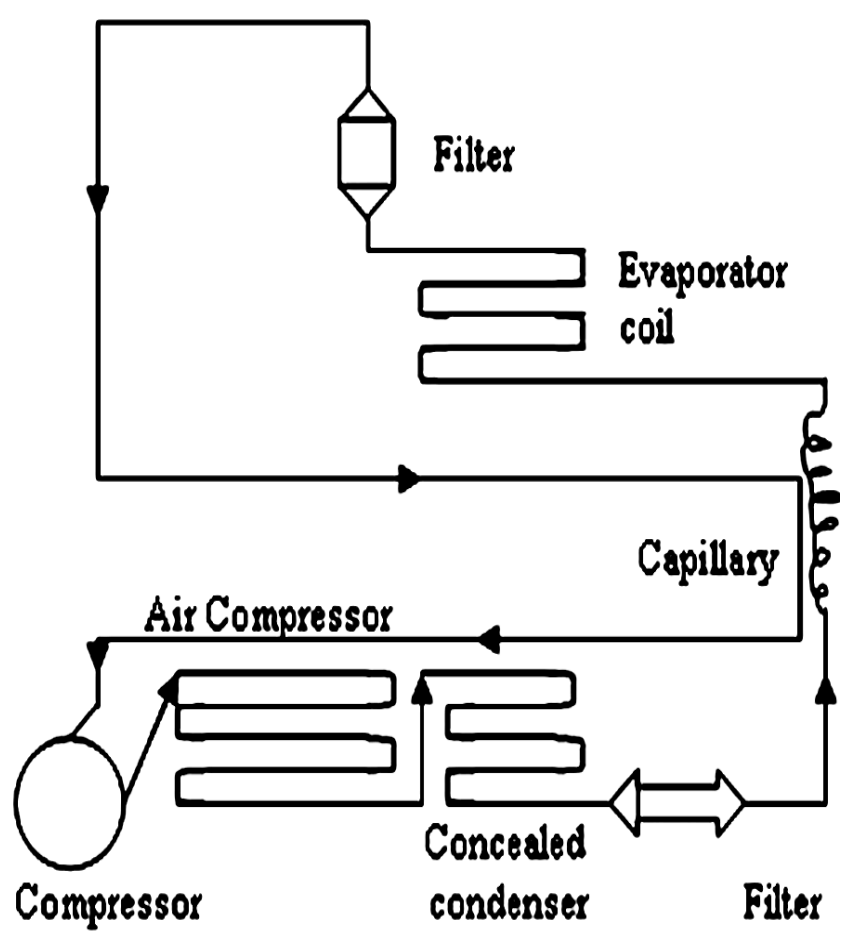

Figure 1. Line diagram of chest freezer.

The cooling load on refrigerating equipment seldom results from any one source of heat but is the summation of the heat evolving from several different sources. The total cooling load can be divided into four separate loads: the wall gain load, the infiltration load, the product load and the miscellaneous load (Kalyani Radha, 2004).

Cooling Load Calculation: The cooling load on refrigerating equipment seldom results from any one source of heat but is the summation of the heat evolving from several different sources (Andrew et al, 2005). Some of the more common sources of heat that is supply the load on refrigerating equipment. 
The design procedure is considered as:

$52 \%$ heat loss due to walls $=89.67 \mathrm{~W}$

$30 \%$ heat loss due to gaskets and air change load $=24.63 \mathrm{~W}$ and $35.64 \mathrm{~W}$

$18 \%$ heat loss due to foodstuffs, heat loss due to defrosting radiant heaters, fans, and thermostat, heat loss due to miscellaneous $=43.53 \mathrm{~W}$

The total load is the sum of all the above loads.

Factor of Safety: Let us consider a factor of safety of $6 \%$ on the total load,

Total Load: $=186.77 \mathrm{~W}$

Safety factor $6 \%: 0.06 \times 186.77=11.20 \mathrm{~W}$

The total load on the freezer: $186.77+11.20=197.97 \mathrm{~W}$

Percentage Run Time:

Let percentage run time $=80 \%$

Required cooling capacity $=197.97 / 0.8=247.46 \mathrm{~W}$

\section{EXPERIMENTAL SETUP AND METHODOLOGY}

The design of the experimental setup is as per the load calculation, selection and optimisation of equipment for a $400 \mathrm{~L}$ chest freezer (specifications in Appendix). The methodology starts with selection of a compressor according to the load calculation, optimum design for other equipment, such as evaporator coil, capillary tube and condenser coil and optimisation of the refrigerant charge quantity in order to be able to withstand break-down conditions.

\section{SELECTION OF EQUIPMENT}

Selection of a Compressor: The required compressor capacity must be determined from the cooling load calculations. General practice is to select a compressor that has a capacity equal to, or somewhat in excess of the required capacity at the design operating conditions ASHRAE $(1965,1977)$. To have a cooling capacity of $247.46 \mathrm{~W}$ from the percentage run time, in order to maintain a temperature of $-23{ }^{\circ} \mathrm{C}$ in a $400 \mathrm{~L}$ chest freezer, we selected a compressor from the compressor cooling performance curves, drawn between evaporating temperature and cooling capacity at $54{ }^{\circ} \mathrm{C}$ condensing temperature. From Figure 2, in order to maintain freezer compartment temperatures of $23{ }^{\circ} \mathrm{C}$, we require $255.81 \mathrm{~W}$ cooling capacities with a rated input power of $250 \mathrm{~W}$. This capacity is more than the cooling load required. The compressor model is a Tecumseh, MLB 2410 series with 2.53 A rated current and $250 \mathrm{~W}$ of rated input power. 

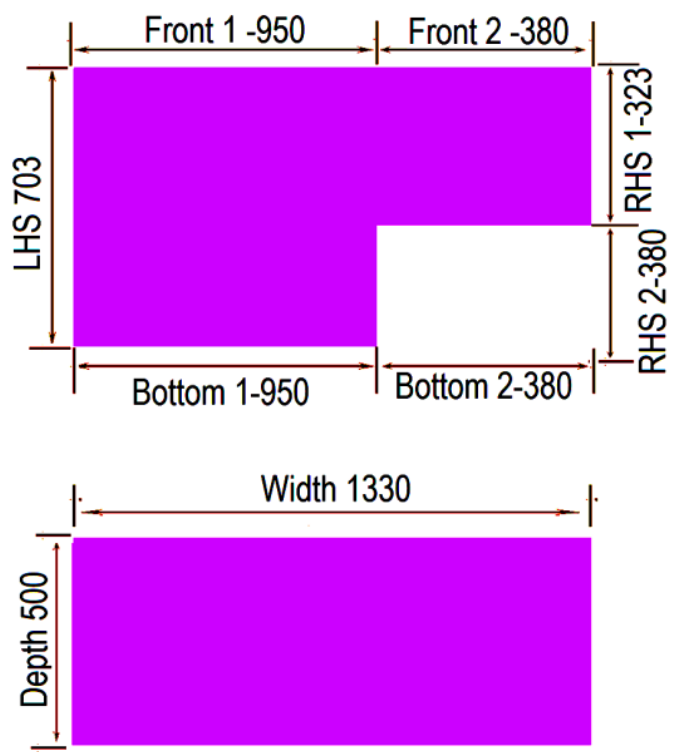

All dimensions are in $\mathrm{mm}$

Figure 2. Dimensions of the chest freezer.

\section{OPTIMUM DESIGN OF EVAPORATOR COIL}

The capacity of an evaporator is the rate at which heat will pass through the evaporator tubes from the refrigerated space or product to the vaporising liquid inside ASHRAE (1977, 1978 and 2001). An evaporator must always have sufficient capacity to produce the required load when operating at the design conditions. The evaporating unit capacity depends on air velocity and minimum dehydration of the product. This is mainly due to natural convection, which is a function of the temperature differential between the evaporator and the space; the greater the difference, the higher the air circulation. The shape, size and location of the evaporator and the placement of the stored product, greatly influences the circulation of air by natural convection within the refrigerated space (Ravindra, 2001). The surface area, the value of $U$ and the capacity of the evaporator depend upon the mean effective temperature difference between the cooling coil and the refrigerated space.

Determination of $\boldsymbol{U}$ factor (Dossat, 2006)

Let $t_{f}$ be the mean film temperature,

$$
t_{f}=\frac{\text { Maximum evaporator temperature }+ \text { minimum evaporator tempeature }}{2}
$$

$t_{f}=-25^{\circ} \mathrm{C}$

The properties of $\mathrm{R} 134 \mathrm{a}$ at $-25^{\circ} \mathrm{C}$ temperature are:

Viscosity of fluid, $\mu_{f}=3.7 \times 10^{-4} \mathrm{~kg} / \mathrm{ms}$

Viscosity of gas, $\mu_{g}=3.9 \times 10^{-4} \mathrm{~kg} / \mathrm{ms}$ 
Density of fluid, $\rho_{f}=1373.5 \mathrm{~kg} / \mathrm{m}^{3}$

Density of gas, $\rho_{g}=46.7 \mathrm{~kg} / \mathrm{m}^{3}$

Latent heat, $h_{f g}=127.45 \mathrm{~kJ} / \mathrm{kg}$

Thermal conductivity of fluid, $K_{f}=0.1031 \mathrm{~W} / \mathrm{m}^{\circ} \mathrm{K}$

Thermal conductivity of gas, $K_{g}=0.0093 \mathrm{~W} / \mathrm{m}^{\circ} \mathrm{K}$

Velocity, $V=3 \mathrm{~m} / \mathrm{s}$

Specific heat, $C_{p}=1.28 \mathrm{~kJ} / \mathrm{kg}^{\circ} \mathrm{K}$

Outer diameter of pipe, $D=7.94 \times 10^{-3} \mathrm{~m}$

Inner diameter, $D_{i}=6.52 \times 10^{-3} \mathrm{~mm}$

Correction factor, $C_{f}=0.065$

Let the Prandtl Number be, $\quad \operatorname{Pr}=\mu_{f} C_{p} / K_{f}=4.5 \times 10^{-3}$

We have, Reynolds Number,

$$
R e=\left[\rho_{g} v D\right] / \mu_{g}
$$

$R e=88423.7>2300$, i.e., it is a turbulent flow.

Let $h_{f g}^{l}$ be the modified latent heat, which can be calculated as:

Let the subcooling temperature difference be $\Delta T_{i}=10{ }^{\circ} \mathrm{C}$

$$
h_{f g}^{1}=h_{f g}+3 / 8 C_{f} \Delta T_{i}=127.69 \mathrm{~kJ} / \mathrm{kg}
$$

The equation for internal flow in the tubes is given by:

$$
\begin{aligned}
& h_{f}=0.555\left[g \rho_{f}\left(\rho_{f}-\rho_{g}\right) K_{f}^{3} h_{f g}^{l} / \mu_{f} \Delta T i D_{i}\right]^{1 / 4} \\
& =310.8 \mathrm{~W} / \mathrm{m}^{\circ} \mathrm{K}
\end{aligned}
$$

As the flow is turbulent, we have the equation for convection heat transfer coefficient as:

$$
h_{i}=1.24(\Delta T / D)^{1 / 3} \quad=13.07 \mathrm{~W} / \mathrm{m}^{\circ} \mathrm{K}
$$

The overall heat transfer coefficient is given by the equation:

$$
U=1 /\left[1 / h_{f}+x_{p} / K_{p}+x_{a} / K_{a}+1 / h_{i}\right]
$$

where, $U=$ coefficient of heat transmission in the evaporating region, $\mathrm{W} / \mathrm{m}^{2}{ }^{\circ} \mathrm{K}$

$x_{c}=$ thickness of outer wall, cold rolled carbon steel, $0.4 \mathrm{~mm}$

$K_{c}=$ thermal conductivity of outer wall, $45.326 \mathrm{~W} / \mathrm{m}^{\circ} \mathrm{K}$

$x_{a}=$ thickness of inner wall, aluminium, $0.45 \mathrm{~mm}$

$K_{a}=$ thermal conductivity of inner wall, $221.95 \mathrm{~W} / \mathrm{m}{ }^{\circ} \mathrm{K}$

$X_{\text {puf }}=$ thickness of insulation, $0.06 \mathrm{~m}$

$K_{\text {puf }}=$ thermal conductivity of insulation material, $0.020 \mathrm{~W} / \mathrm{m}^{\circ} \mathrm{K}$ per metre thickness

$h_{i}=$ inside wall surface coefficient, $13.7 \mathrm{~W} / \mathrm{m}^{2}{ }^{\circ} \mathrm{K}$

Therefore, $U_{1}=11.16 \mathrm{~W} / \mathrm{m}^{2}{ }^{\circ} \mathrm{K}$

The mean effective temperature difference is calculated by:

$$
\Delta T=T M-T E
$$


where, $T M=$ mean temperature inside freezer, ${ }^{\circ} \mathrm{C}$

$T E=$ Evaporator temperature, $-30{ }^{\circ} \mathrm{C}$ from ASHRAE

It is assumed that the evaporator temperature is maintained at $7{ }^{\circ} \mathrm{C}$ below the temperature maintained inside the freezer cabinet.

From the equation, $\quad T M=T F \times C F$

where

$T F=$ the temperature of frozen food storage compartment, $-23^{\circ} \mathrm{C}$

$C F=$ the air quantity ratio of frozen storage compartment in percentage from ASHRAE

From the above equation, $T M=T F \times C F=-23 \times 0.4=-9.2^{\circ} \mathrm{C}$

We have

$$
\Delta T=T M-T E=-9.2-(-30)=20.8^{\circ} \mathrm{C}
$$

Heat absorbed in evaporator is given by: $\quad Q=U A \Delta T$

$$
A=\prod d l
$$

For the design procedure of the evaporator coil, the total load to be removed from the freezer compartment $=197.97 \mathrm{~W}$

$$
\Delta T=20.8^{\circ} \mathrm{K}, U=11.16 \mathrm{~W} / \mathrm{m}^{2}{ }^{\circ} \mathrm{K}
$$

Substituting these values in the equation, $\quad Q=U A \Delta T$

$$
A=0.852 \text { Sq. m }
$$

Let the diameter of the coil, $d=7.94 \mathrm{~mm}$, then $L=34.15 \mathrm{~m} \sim 34 \mathrm{~m}$ length.

\section{OPTIMUM DESIGN OF A CAPILLARY TUBE}

In order to select the proper size valve, the following data are necessary: the evaporator temperature, the system capacity and the available pressure difference across the valve ASHRAE (1977 and 1978). In general, the first two factors determine the required liquid flow rate through the valve, whereas the third determines the size of orifice required to deliver the desired flow rate; the flow rate through the orifice being proportional to the pressure differential across the valve (Dossat, 2006; Stoecker, 2009). When the available pressure difference across the expansion valve has been determined, a value should be selected from the manufacturers rating table that has a capacity equal to, or slightly in excess of the system capacity at the system design operating conditions. This can be only achieved by testing.

The Darcy Friction Equation gives the pressure drop:

$$
\Delta P=f L c V^{2} / 2 g D c
$$

where: $\Delta P=$ drop in pressure in capillary

$L c=$ length of the capillary

$D c=$ diameter of the capillary 
From the P-h chart, $\Delta \mathrm{P} 1=0.668$ bar and $\Delta \mathrm{P} 2=12.38$ bar, $\mathrm{f}=0.004, \mathrm{~g}=9.81$ $\mathrm{m} / \mathrm{sec}^{2}$. From ASHRAE, the recommended velocity of flow for the discharge and suction pressure, $\mathrm{v}=3.67 \mathrm{~m} / \mathrm{sec}$, therefore $\Delta \mathrm{P}=11.71$ bar. From ASHREA standards, for a pressure drop of $11.71 \mathrm{bar}$, the dimensions should be $\mathrm{D}=0.79 \mathrm{~mm}, \mathrm{~L}=3.963 \mathrm{~m}$.

\section{OPTIMUM DESIGN OF A CONDENSER COIL}

While designing the actual refrigeration cycle (Ravindra, 2001), the condenser load is expressed by following Eq. (14). However, the required capacity is $197.97 \mathrm{~W}$, which is more than the refrigeration load, so in designing the condenser coil we have to consider this load to be the refrigeration load, as this increases the load on capacity of the condenser coil.

$$
\begin{gathered}
Q_{\text {condenser }}=Q_{\text {refrigeration capacity }}+\text { Compressor Input Power } \\
=197.97+250=447.97 \mathrm{~W}
\end{gathered}
$$

We have the equation, heat rejected in condenser, $Q_{\text {condenser }}=F U A \Delta T$

where $F=$ correction factor depending on the $R$ and $P$ values.

Therefore, $447.97 \mathrm{~W}$ of heat should be removed from the condenser coil. As it is difficult to remove the total amount of heat through natural convection, we employ a condenser fan placed in front of an auxiliary condenser and the rest of the condenser coil is attached to the outer shell of the cabinet.

Log mean temperature difference, $\Delta T=29.49^{\circ} \mathrm{K}$

From Eq. 15, the surface area of the condenser coil can be calculated.

Let the outer diameter of the coil, $d=6.52 \mathrm{~mm}$

$$
\begin{aligned}
& A=\prod d L=0.7843 \mathrm{~m}^{2} \\
& L=38.29 \mathrm{~m}
\end{aligned}
$$

\section{RESULTS AND DISCUSSION}

\section{Optimisation of Refrigerant Charge Quantity}

The system is first charged with $400 \mathrm{~g}$ of charge as per the compressor specifications and then the system is tested for stabilisation of temperatures (Kalyani Radha, 2004; ASHRAE 2005). Every $4 \mathrm{~h}, 10 \mathrm{~g}$ of charge is purged from the system and each time it is tested for stabilised conditions. Figure 3 shows that a $320 \mathrm{~g}$ of charge is sufficient to maintain the required stabilised temperatures inside the freezer cabinet at $1.89 \mathrm{~A}$ and a rated input power of $190 \mathrm{~W}$. 


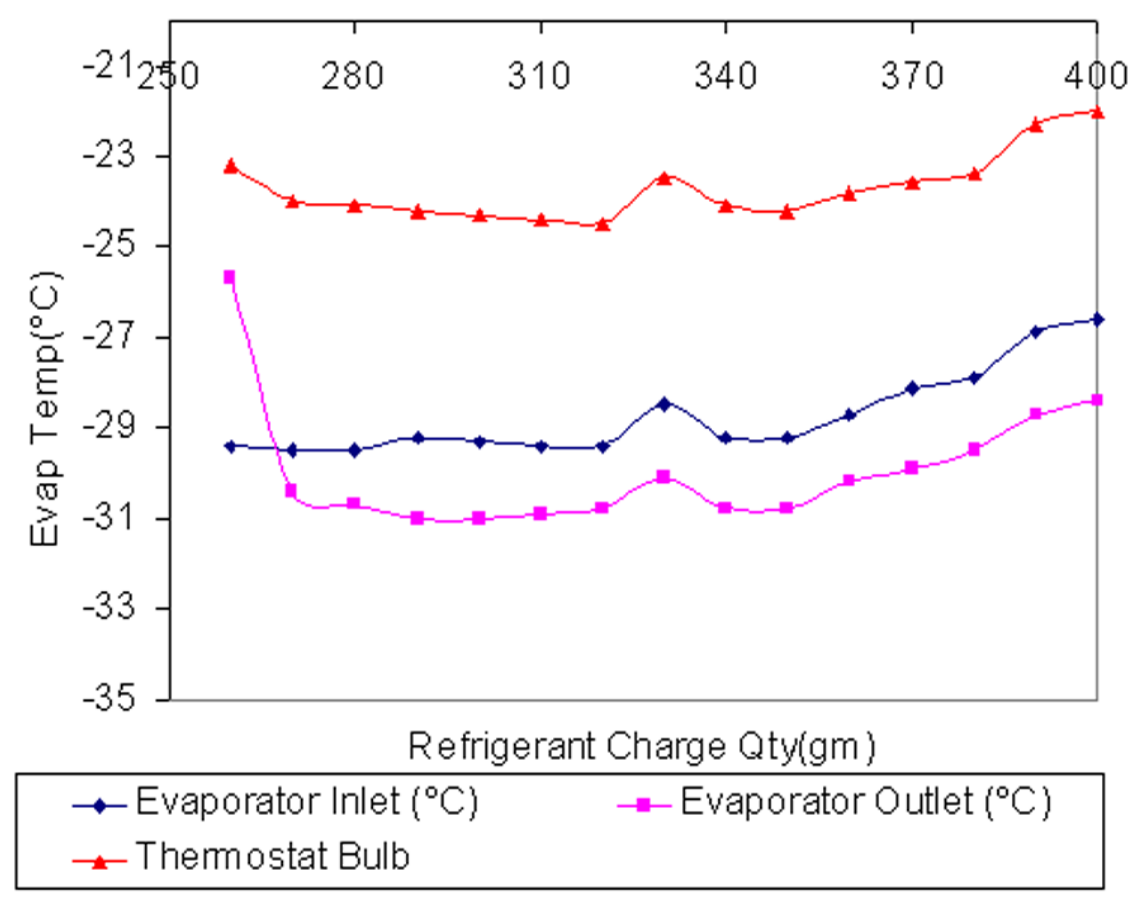

Figure 3. Evaporator temperature vs. refrigerant charge quantity.

\section{No Load Pull Down Test}

The system is run for about $4 \mathrm{~h}$ without the thermostat in the refrigeration cycle. After achieving a steady state, the performance is analysed between temperature and time (Figure 4). It is achieving a steady state requires $1.772 \mathrm{~A}$ at a rated input power of 198W.

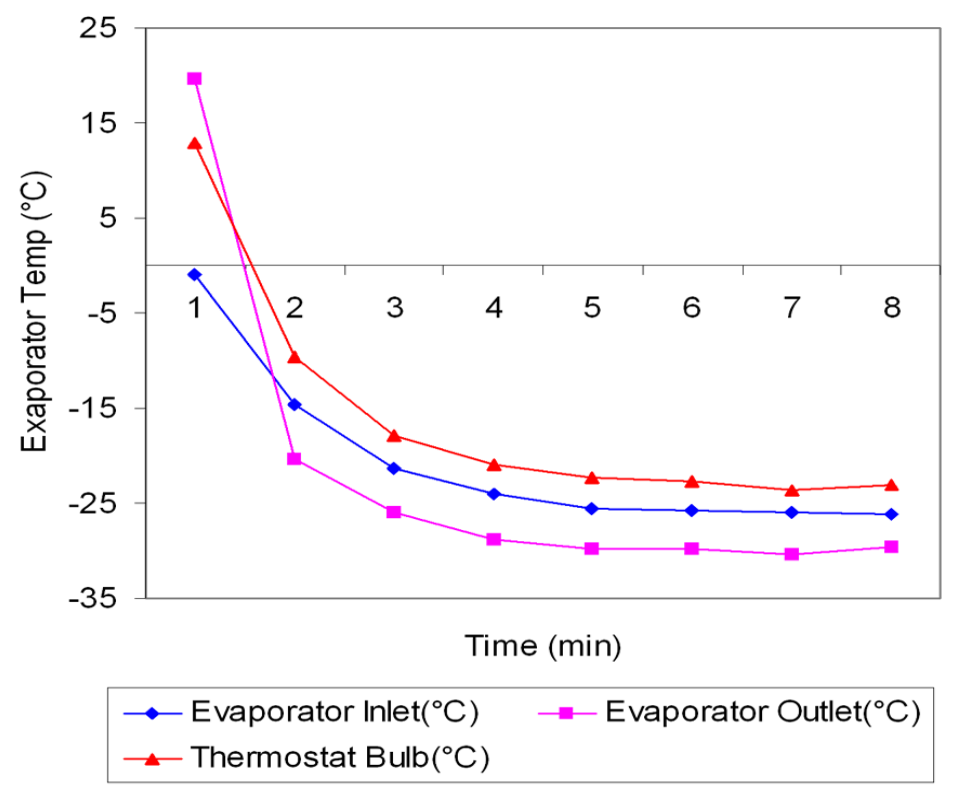

Figure 4. No load pull down - evaporator temperature vs. time. 


\section{No-load Cycling Test}

The system is run keeping the thermostat in cycling mode in the refrigeration system. As the temperature reaches $-23.5{ }^{\circ} \mathrm{C}$ the compressor stops, which is called the cut-off time and as the temperature inside the cabinet reaches $-20{ }^{\circ} \mathrm{C}$ the compressor starts, which is called the cut-in time; taking the power and maintaining the temperature inside the cabinet at stabilised conditions. The system is run for $5 \mathrm{~h}$ and its performance is analysed (Figure 5).

Cut-off time $=1 \mathrm{~h}$ and $16 \mathrm{~min}=76 \mathrm{~min}$

Cut-in time (run time) $=4 \mathrm{~h}$ and $16 \mathrm{~min}=256 \mathrm{~min}$

Total time $=$ cut-off time + cut-in time $=76+256=332 \mathrm{~min}$

Run percentage time $=($ run time $/$ Total time $) \times 100=77 \%$

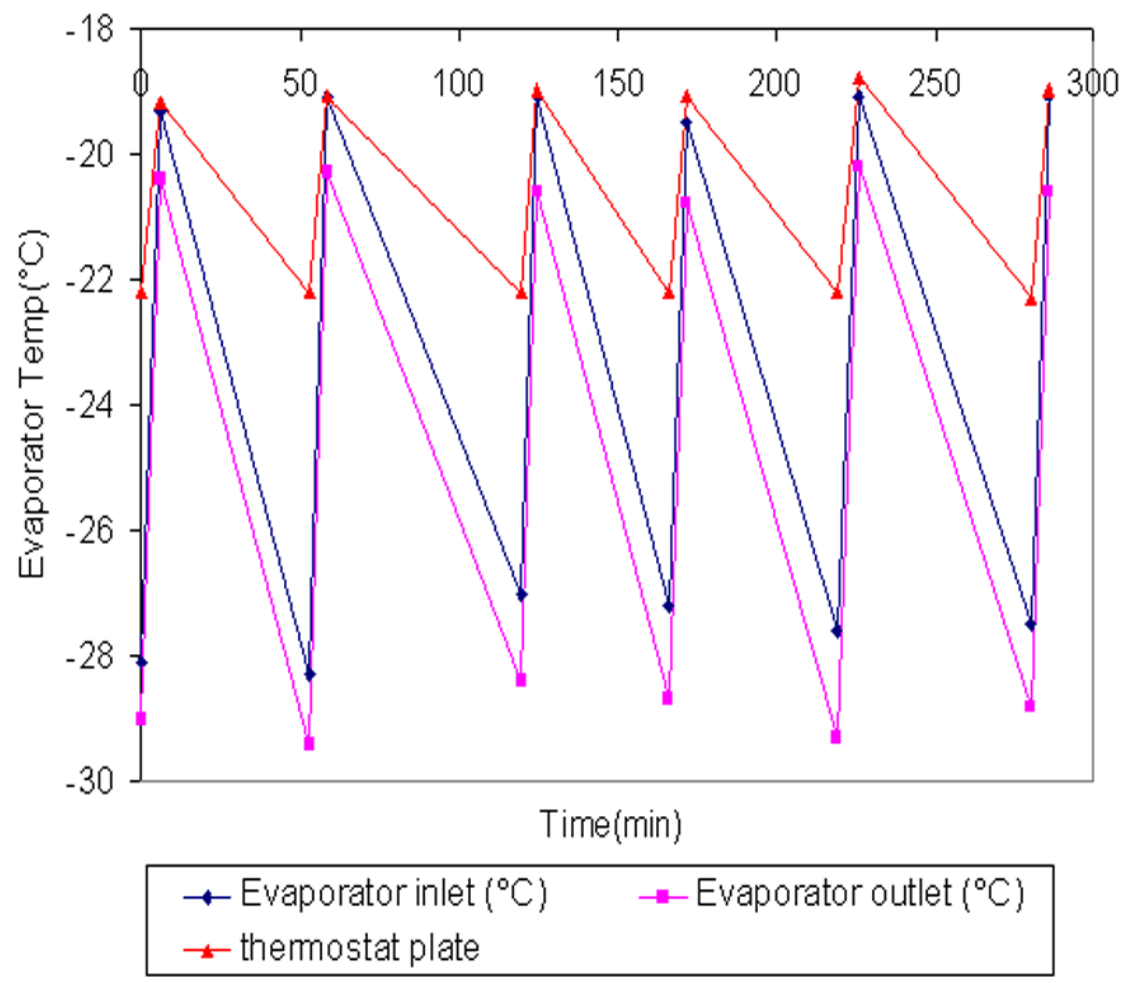

Figure 5. No load cycling - evaporator temperature vs. time.

\section{Load Pull Down Test}

The system operates for $24 \mathrm{~h}$ at full load conditions. From Figure 6, we can say that the system achieves steady state conditions after 16 to $18 \mathrm{~h}$. The suction pressure is 0.66 bar and the discharge pressure is 12.38 bar, which takes almost $1.83 \mathrm{~A}$ of rated current and $215 \mathrm{~W}$ of rated power. This would be the maximum power required to pull down the total load from the cabinet. 


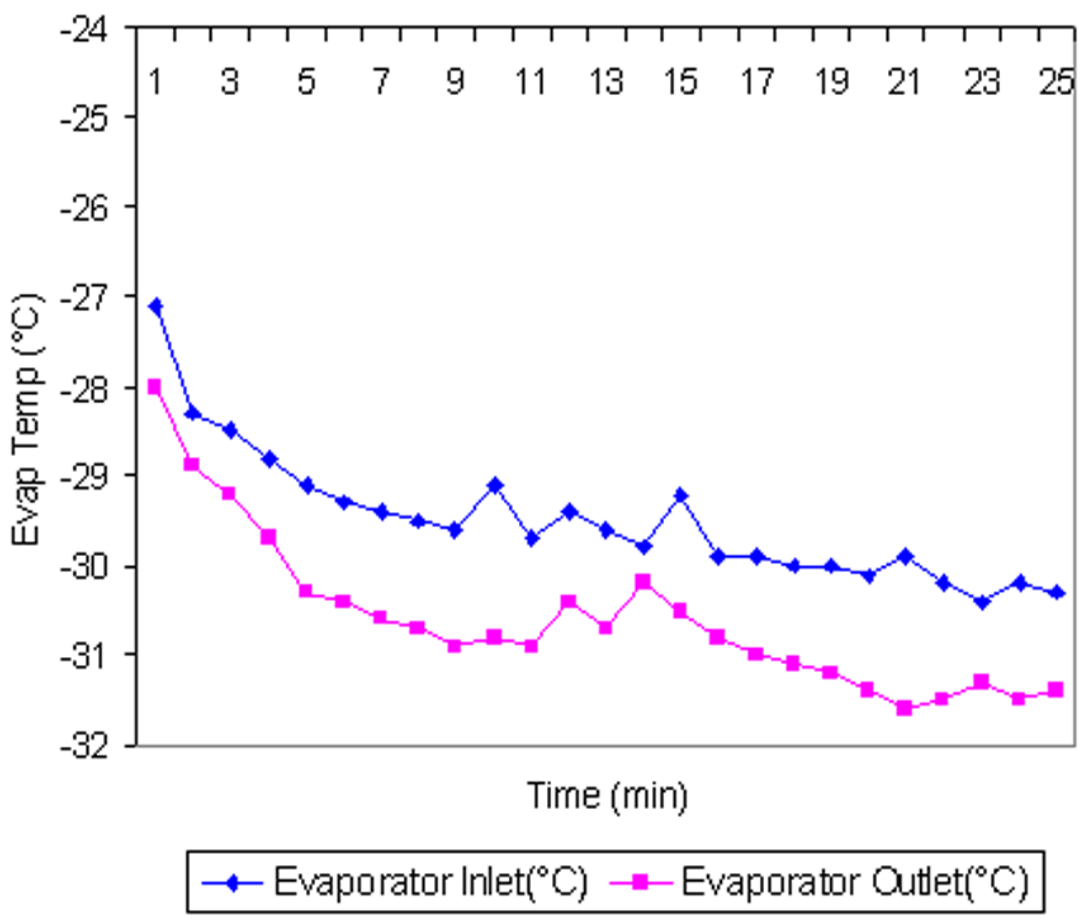

Figure 6. Load pull down - evaporator temperature vs. time.

\section{Energy Consumption}

At Full Load condition,

Initial reading $=4005.08 \mathrm{kWhr}$

Final reading $=4009.33 \mathrm{kWhr}$

Total Power $=4009.33-4005.08=4.25 \mathrm{kWhr} / 24 \mathrm{hr}$

\section{Load Pull Up Test}

After the system runs continuously for about $24 \mathrm{~h}$ the supply is switched off. The temperature of all the side packets are noted until one packet reaches $-9{ }^{\circ} \mathrm{C}$, which is the temperature when the loaded product inside the freezer just starts crossing its freezing point and if continued further, the product begins to be damaged. The total pull up time $=8 \mathrm{~h}$. This is the time required to store the product without any spoiling inside the freezer at power off conditions (Figure 7).

If all other parameters are kept the same but we change the refrigerant from $\mathrm{R} 12$ to $\mathrm{R} 134 \mathrm{a}$, temperatures of $-23{ }^{\circ} \mathrm{C}$ can be maintained inside the freezer cabinet, at $43^{\circ} \mathrm{C}$ ambient, with low power consumption and an increase in the net refrigerating effect, which in turn increases the COP by $4.25 \%$. The refrigerant charge quantity is reduced by $29.4 \%$ with an increase in performance during breakdown conditions. The optimised evaporator coil length and diameter are $34.15 \mathrm{~m}$ and $7.94 \mathrm{~mm}$, respectively. The two refrigerants are compared, as shown in Table 1. 
Table 1. Comparison of R12 and R134a.

\begin{tabular}{|c|c|c|c|}
\hline & Properties & R12 & R134a \\
\hline 1 & ODP & 0.86 & 0 \\
\hline 2 & GWP & 3.2 & 0.27 \\
\hline 3 & Evaporator Coils & Copper & $\begin{array}{l}\text { Mild steel inside, copper } \\
\text { coating outside zinc coated }\end{array}$ \\
\hline 4 & Temperature & $-18^{\circ} \mathrm{C}$ & $-23{ }^{\circ} \mathrm{C}$ \\
\hline 5 & $\begin{array}{c}\text { Energy } \\
\text { Consumption/day }\end{array}$ & $6 \mathrm{kWhr}$ & $4.25 \mathrm{kWhr}$ \\
\hline 6 & $\begin{array}{l}\text { During power-off / } \\
\text { Breakdown condition }\end{array}$ & 4 to $6 \mathrm{~h}$ & $8 \mathrm{~h}$ \\
\hline 7 & $\begin{array}{c}\text { Net refrigerating } \\
\text { effect }\end{array}$ & $105 \mathrm{~kJ} / \mathrm{kg}$ & $118 \mathrm{~kJ} / \mathrm{kg}$ \\
\hline 8 & $\begin{array}{l}\text { Mass flow of } \\
\text { refrigerant }\end{array}$ & $0.0017 \mathrm{~kg} / \mathrm{s}$ & $0.0012 \mathrm{~kg} / \mathrm{s}$ \\
\hline 9 & Work done & $13 \mathrm{~kJ} / \mathrm{kg}$ & $14 \mathrm{~kJ} / \mathrm{kg}$ \\
\hline 10 & $\mathrm{COP}$ & 8.076 & 8.42 \\
\hline
\end{tabular}

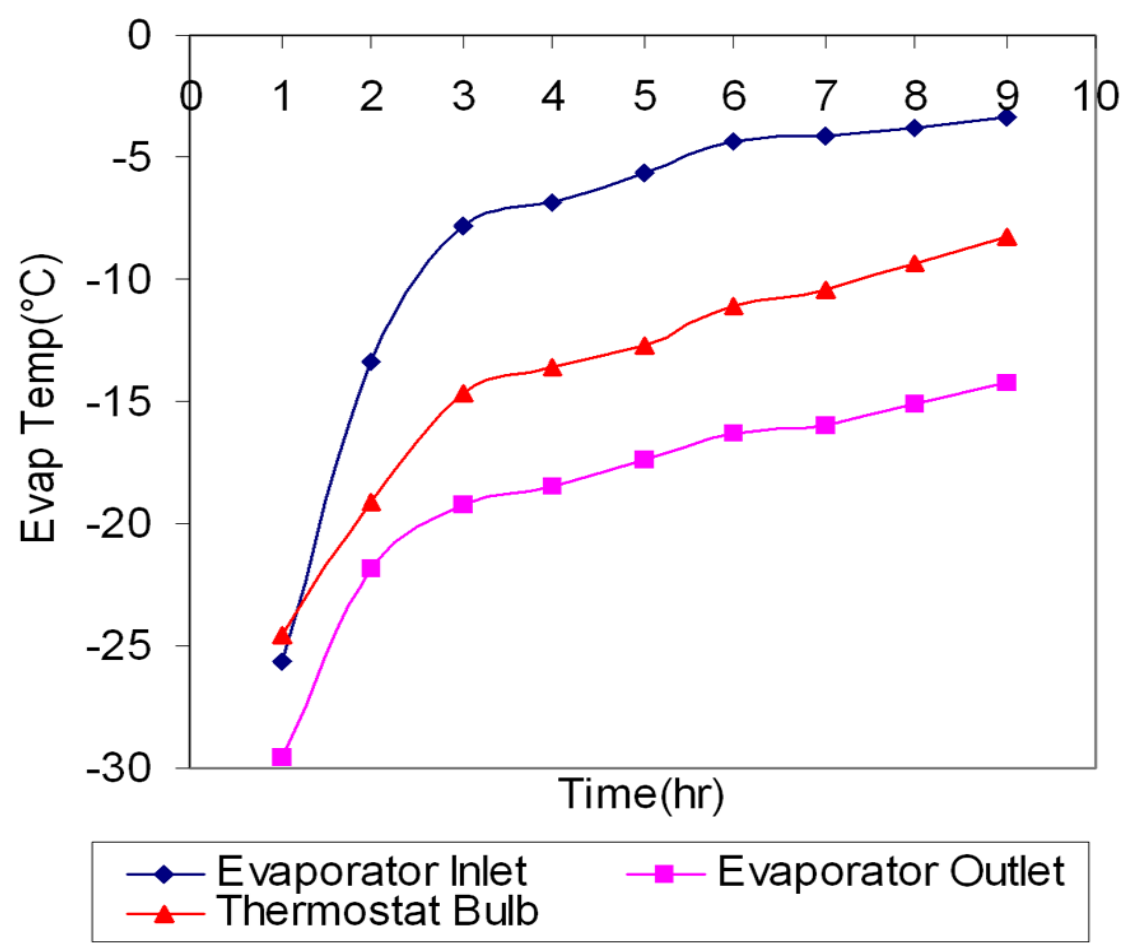

Figure 7. Load pull up - evaporator temperature vs. Time. 


\section{CONCLUSION}

In the design of the refrigeration system for a freezer, rigid standards are maintained so as not to have any compromise with the quality and flexibility of the system. The system is designed for optimum efficiency with moderate costs; efficient equipment design will result in energy savings, which reduces the running costs. The performance of the total system can be enhanced by removing dust particles or contaminants from the system. Placement of the freezer also plays a major role in reducing the load on the system. If exposed to the higher temperatures, the greater will be the capacity requirement and power requirement. Future work would be the development of an even more energy efficient freezer for working at different ambient conditions and with alternative refrigerants, which is more economical and more feasible at breakdown conditions. In addition, a new chest freezer model is to be designed, maintaining the freezing temperatures below $0{ }^{\circ} \mathrm{F}$, at $80-95 \%$ relative humidity for the storage of frozen food.

\section{ACKNOWLEDGEMENTS}

The authors are thankful to the Voltas, $\mathrm{R}$ and $\mathrm{D}$ Unit, Hyderabad for providing the facilities in order to carry out this work.

\section{REFERENCES}

Akash, B.A., Said, S.A., 2003. Assessment of LPG as a possible alternative to R-12 in domestic refrigerators. Energy Conversion and Management 44(3): 381-388.

Althouse, A.D., Turnquist, C.H. and Bracciano, A.F. 2005. Modern refrigeration and air-conditioning. Tinley Park: The Goodheart-Willcox. Co., Inc.

American National Standards Institute/ ASHRAE, 2005. Standard 722005: Method of testing commercial refrigerators and freezers.

ASHRAE, Guide and Data Book, 1965. Fundamentals and equipment.

ASHRAE, Guide and Data Book, 1977. Fundamentals and equipment.

ASHRAE, Guide and Data Book, 1978. Product directory applications.

ASHRAE, Guide and Data Book, 2001. Fundamentals.

Avinash, P., Jabaraj, D.B. and Lal, D.M. 2005. Beyond HCFC22 for air conditioners an outlook. IRHACE Journal, 20-23.

Baolian, N. and Zhang, Y. 2006. Experimental study of the refrigeration cycle performance for the R744/R290 mixtures. International Journal of Refrigeration $30,37-42$.

Calm, J.M. 2006. Comparative efficiencies and implications for greenhouse gas emissions of chiller refrigerants. International Journal of Refrigeration, 29: 833841.

Dossat, R.J., 2006. Principles of refrigeration. New York: John Wiley and Sons, Inc.

Fatouh, M. and El Kafafy, M. 2006. Experimental evaluation of a domestic refrigerator working with LPG. Applied Thermal Engineering, 26: 1593-1603.

He, M.G., Li, T.C., Liu, Z.G. and Zhang, Y. 2005. Testing of the mixing refrigerant HFC152a/HFC125 in domestic refrigerator. Applied Thermal Engineering, 25: $1169-1181$.

H-IM-64L. 2007. Installation and operational manual. Heatcraft worldwide refrigeration. 
Jabaraj, D.B., Avinash, P., Mohanlal, D. and Renganarayanan, S. 2006. Experimental investigation of HFC407C/HC290/HC600a mixture in window air conditioner. Energy Conservation and Management, 48: 3084-3089.

Kalyani Radha. K, 2004. To develop a novel chest freezer, M.Tech Thesis. Department of Mechanical Engineering, JNTU College of Engineering, Anatapur, Andhra Pradesh, India.

KIRLOSKAR COPELAND Technical Manual, 2005. Karad.

Lee, Y.S. and Su, C.C. 2002. Experimental studies of isobutene (R600a) as refrigerant in domestic refrigeration system. Applied Thermal Engineering ,22: 507-519.

MOEF (Ministry of environment and forest). 2005. Government of India. Ozone depleting substances (regulation and control) rules, ozone cell India (www.ozonecell.com).

Mohanraj, M., Jayaraj, S. and Muraleedharan, C. 2009. Environment friendly alternatives to halogenated refrigerants-A review. International Journal of Greenhouse Gas Control, 3:1 08-119.

Park, K.J. and Jung, D.S. 2007. Thermodynamic performance of R502 alternative refrigerant mixtures for low temperature and transport applications. Energy Conversion and Management, 48(12): 3084-3089.

Poggi, F., Macchi-Tejeda, H., Leducq, D. and Bontemps, A. 2008. Refrigerant charge in refrigerating systems and strategies of charge reduction. International Journal of Refrigeration, 31(3): 353-370.

Ravindra, D. 2001. Air cooled condensers; types, ratings, design, construction, installation and maintenance. Air-conditioning and Refrigeration Journal. JulySeptember issue. (http://www.ishrae.in/journals/2001july/article03.html)

Stoecker, W.F. and Jones, J.W. 2003. Refrigeration and air-conditioning. Singapore: McGraw-Hill Book Company.

TECUMSEH Technical Manual, Ballabgarh.

Xuan, Y. and Chen, G. 2005. Experimental study on HFC161 mixture as an alternative refrigerant to R502. International Journal of Refrigeration, 28: 436-441.

\section{Nomenclature}

$\begin{array}{ll}\text { A } & \text { Surface Area, } \mathrm{m}^{2} \\ \text { COP } & \text { Coefficient of Performance } \\ \mathrm{d} / \mathrm{D} & \text { Diameter, } \mathrm{mm} \\ \mathrm{l} & \text { Length, } \mathrm{m} \\ \mathrm{m}_{\mathrm{r}} & \text { Mass of Refrigerant, } \mathrm{kg} \\ \mathrm{Q} & \text { Total Heat Transfer, } \mathrm{W} \\ \mathrm{t}_{\mathrm{o}} & \text { Outside Temperature, }{ }^{\circ} \mathrm{C} \\ \mathrm{t}_{\mathrm{i}} & \text { Inside Designed Temperature, }{ }^{\circ} \mathrm{C} \\ \mathrm{t}_{\mathrm{f}} & \text { Mean Film Temperature, }{ }^{\circ} \mathrm{C} \\ \Delta \mathrm{T} & \text { Difference in Temperature, }{ }^{\circ} \mathrm{C} \\ \mathrm{U} & \text { Overall Heat Transfer Coefficient, } \mathrm{W} / \mathrm{m}^{2 \circ} \mathrm{K}\end{array}$




\section{APPENDIX}

\section{CHEST FREEZER SPECIFICATIONS}

Capacity

Overall dimensions

Outer body

Inner cabinet

Insulation
$400 \mathrm{~L}$

$1450 \times 895 \times 620 \mathrm{~mm}$

Cold rolled carbon steel ( $0.4 \mathrm{~mm}$ thickness)

Aluminium (0.45 mm thickness)

polyol, cyclopentane and isocyanate PUF

(60 mm thickness). 